\title{
Peningkatan Kemampuan Melakukan Operasi Hitung Dengan Menerapkan Model Penugasan pada Sekolah Dasar
}

\author{
MAILISNUR \\ Sekolah Dasar Negeri 023 Pandau Jaya \\ Jln. AR. Rahim IV No. 1 Siak Hulu, Kampar \\ E-mail : mailisnur@yahoo.com
}

\begin{abstract}
Abstract: Methods of learning in mathematics becomes a unique challenge for math teachers in presenting the material to learners. Its success in providing the raw material effectively becomes a reference for learning. Through action research on class $\mathrm{V}$ subjects applied mathematics assignment models and analyzed descriptively. Based on the survey results revealed that the application of learning etode assignment in order to improve the results of student homework in class $\mathrm{V}$ in mathematics on the integer turns learning outcomes of students increased significantly. The data obtained show that after the implementation of the method of learning assignment, then proved their influence in a positive direction in improving the results of student homework in mathematics concerning arithmetic operations.

Keywords:
\end{abstract}

Keywords: Assignment Method, Learning Ability

Perkembangan di bidang ilmu pengetahuan dan teknologi serta dalam menyiapkan sumber daya manusia yang berkualitas, untuk mencerdaskan kehidupan bangsa Indonesia melalui pendidikan. Pernyataan tersebut sesuai dengan tujuan pendidikan nasional yang tertuang dalam undang-undang nomor 20 tahun $2003 \mathrm{Bab}$ 2 , pasal 3, tentang sistem pendidikan nasional.(Ni Made Sunilawati, Nyoman Dantes, 2013)

Guru dalam pelaksanaan pembelajaran mempunyai tanggung jawab profesional untuk mewujudkan tujuan pendidikan nasional. Guru harus menyajikan pembelajaran yang menarik dan menyenangkan bagi peserta didik agar tercapainya suatu kompetensi dan profesionalisme guru dalam kegiatan pembelajaran. Guru berperan sangat penting dalam kegiatan pembelajaran, karena guru bertanggungjawab terhadap tujuan-tujuan pembelajaran yang ingin dicapai secara optimal. Selain sebagai tenaga pendidik dan pengajar tugas utama guru di sekolah adalah sebagai fasilitator sekaligus motivator. Dalam kegiatan pembelajaran peran guru sebagai fasilitator hendaknya memfasilitasi siswa dalam kegiatan pembelajaran, sedangkan guru sebagai motivator dimaksudkan guru memotivator siswa agar implikasi pembelajaran mengarahkan pada pembelajaran efektif dan efisien.(Ni Made Sunilawati, Nyoman Dantes, 2013)

Pada pelajaran matematika adalah ilmu pengetahuan tentang struktur yang terorganisasikan didasarkan pada unsurunsur tidak terdefinisi, aksioma atau postulat dan dapat diturunkan menjadi teorema atau dalil yang pembuktiannya dapat diterima secara deduktif. Deduktif dalam arti mengandalkan beberapa fakta yang sebelumnya dianggap benar dan simpulan akhir yang ditarik merupakan konsekuensi logis dari fakta-fakta tersebut yang sebelumnya telah diketahui(Ni Made Sunilawati, Nyoman Dantes, 2013)

Metode pembelajaran Menurut Djamarah metode resitasi (penugasan) adalah metode penyajian bahan dimana guru memberikan tugas tertentu agar siswa melakukan kegiatan belajar. Sedangkan menurut Mulyani Sumantri mengemukakan bahwa "Metode pemberian tugas atau penugasan diartikan sebagai suatu cara interaksi belajar mengajar yang ditandai dengan adanya 
tugas dari guru untuk dikerjakan peserta didik di sekolah ataupun di rumah secara perorangan atau berkelompok". Dalam literatur (Roestiyah) yang dijelaskan bahwa pemberian tugas dapat diartikan pekerjaan rumah, tetapi sebenarnya ada perbedaan antara pemberian tugas dan pekerjaan rumah, untuk pekerjaan rumah guru menyuruh siswa membaca buku kemudian memberi pertanyaan- pertanyaan di kelas, tetapi dalam pemberian tugas guru menyuruh siswa membaca dan menambahkan tugas. (Alamati, 2013)

Mengajar merupakan tugas pokok seorang guru. Guru yang terampil mengajar dapat merasakan bahwa mengajar merupakan suatu hal yang mengembirakan, yang membuatnya melupakan kelelahan.Mengajar merupakan bagian dari seni.Namun tidak semua guru dapat merasakan hal yang demikian. Hal ini disebabkan oleh sulitnya mencari metode mengajar yang tepat. Selama ini tidak ada pegangan yang pasti bagi seorang guru untuk mendapatkan metode mengajar yang paling tepat.Tepat atau tidaknya suatu metode baru terbukti setelah mengetahui hasil belajar peserta didik.Berdasarkan hal ini dapat dipahami bahwa betapa pentingnya seorang guru menguasai ilmu metode pembelajaran. (Masjoko, 2015)

Sebelum memilih dan menentukan metode pembelajaran yang akan digunakan, guru terlebih dahulu perlu melihat faktor apa saja yang mempengaruhi siswa dalam belajar selanjutnya baru bisa dilakukan penentuan metode pembelajaran yang tepat. Hal ini berarti bahwa butuh waktu yang lama untuk menentukan metode pembelajaran yang dianggap cocok untuk kondisi peserta didik, sementara waktu terus berlalu dan materi pelajaran harus disampaikan sesuai dengan silabus yang ada. (Masjoko, 2015)

Di dalam proses belajar mengajar tercakup komponen, pendekatan, dan berbagai metode pengajaran yang dikembangkan dalam proses tersebut. Tujuan utama diselenggarakannya proses belajar adalah demi tercapainya tujuan pembelajaran. Dan tujuan tersebut utamanya adalah keberhasilan siswa dalam belajar dalam rangka pendidikan baik dalam suatu mata pelajaran maupun pendidikan pada umumnya. Jika guru terlibat di dalamnya dengan segala macam metode yang dikembangkannya maka yang berperan sebagai pengajar berfungsi sebagai pemimpin belajar atau fasilitator belajar, sedangkan siswa berperan sebagai pelajar atau individu yang belajar. Usahausaha guru dalam proses tersebut utamanya adalah membelajarkan siswa agar tujuan khusus maupun umum proses belajar itu tercapai.(Krismanto, 2003)

Usaha-usaha guru dalam mengatur dan menggunakan berbagai variabel pengajaran merupakan bagian penting dalam keberhasilan siswa mencapai tujuan yang direncanakan. Karena itu maka pemilihan metode, strategi dan pendekatan dalam situasi kelas yang bersangkutan sangat penting. Upaya pengembangan strategi mengajar tersebut berlandas pada pengertian bahwa mengajar merupakan suatu bentuk upaya memberikan bimbingan kepada siswa untuk melakukan kegiatan belajar atau dengan kata lain membelajarkan siswa seperti disebut di atas. Dari sini tercermin suatu pengertian bahwa belajar tidak semata-mata berorientasi kepada hasil, melainkan juga berorientasi kepada proses. Kualitas proses akan memberikan iur dalam menentukan kualitas hasil yang dicapai.(Krismanto, 2003)

Metode berarti suatu cara yang dpergunakan untuk mencapai tujuan yang telah ditetapkan. Perumusan tentang metode menurut Runes, Dagobet sebagaimana yang dikutip oleh Sudirjo adalah "any procedure employed attaina certain end". Definisi ini mengandung pengetian bahwa metode adalah suatu prosedur yang digunakan untuk mencapai tujuan tertentu. Pemberian yaitu menyerahkan sesuatu kepada orang lain. (Saryanti, 2010)

sedangkan tugas yaitu sesuatu yang wajib dikerjakan atau ditentukan

p.ISSN: $2407-800 X \quad$ e.ISSN: 2541-4356 
untuk dilakukan. Jadi pemberian tugas adalah menyerahkan sesuatu kepada orang lain yang wajib dikerjakan. Metode penugasan merupakan cara penyajian bahan pelajaran dimana guru memberikan seperangkat tugas yan harus dkerjakan oleh peserta didik baik secara individu maupun secara kelompok untuk mencapai tujuan yang telah dirumuskan (Saryanti, 2010)

Dalam memberikan tugas, guru dianjurkan memperhatikan hal - hal sebagai berikut: Tugas yang diberikan harus berhubungan erat dengan materi pelajaran yang telah disajikan. Tugas yang diberikan harus sesuai dengan kesanggupan ranah cipta ranah karsa siswa. Tugas yang diberikan harus sesuai dengan kesanggupan ranah siswa siswa, dalam arti tidak berlawanan dengan sikap dan perasaan batinnya, sehingga ia dapat melaksanakan tugas dengan senang hati. Tugas yang diberikan hari jelas baik jenis, volume maupun batas waktu penyelesaian. (Saryanti, 2010)

Oleh karenanya, dalam mempelajari mata pelajaran matematika pada siswa sekolah dasar, apakah dengan penerapan metode penugasan dapat meningkatkan kemampuannya dalam belajar, maka inilah yang memotivasi dalam penelitian ini.

\section{METODE}

Metode yang digunakan dalam penelitian ini adalah metode penelitian tindakan kelas. penelitian ini dilakukan karena ditemukan permasalahan rendahnya hasil belajar mata pelajaran matematika mengenai bilangan bulat. Permasalahan ini ditindaklanjuti dengan cara menerapkan sebuah metode pembelajaran kooperatif yang dilakukan oleh guru kelas. Kegiatan tersebut diamati kemudian dianalisis dan direfleksi. Hasil revisi kemudian diterapkan kembali pada siklus-siklus berikutnya.

Tindakan yang dilakukan dalam penelitian ini adalah menerapakan metode belajar penugasan kepada siswa dalam rangka meningkatkan kemampuan melakukan operasi hitung campuran bilangan bulat kelas V mata pelajaran Matematika mengenai bilangan bulat SD N 023 Pandau Jaya Kampar. Karena keterbatasan waktu, penelitian tindakan kelas ini hanya dilaksanakan sebanyak 2 siklus masingmasing siklus dilaksanakan selama 1 minggu.

Teknik pengumpulan data dari penelitian tindakan sekolah ini adalah melalui data kualitatif yang diperoleh dari observasi, pengamatan, maupun wawancara. Analisa data yang digunakan dalam penelitian ini adalah analisa data kualitatif yang bersumber dari data primer maupun empiris.

\section{HASIL}

Penelitian tindakan kelas (PTK) ini dilaksanakan dalam dua siklus. Hal ini dikarenakan keterbatasan waktu yang tersedia, serta dengan dua siklus sudah penulis anggap cukup untuk peningkatan hasil penugasan siswa pada mata pelajaran matematika mengenai bilangan bulat di kelas.

Hasil pekerjaan rumah siswa pada mata pelajaran matematika mengenai bilangan bulat melalui metode belajar penugasan di kelas $\mathrm{V}$ dilihat dari hasil pekerjaan rumah dapat dilihat pada tabel rekap berikut:

Tabel 1: Hasil pekerjaan rumah siswa pada mata pelajaran matematika mengenai bilangan bulat melalui metode belajar penugasan

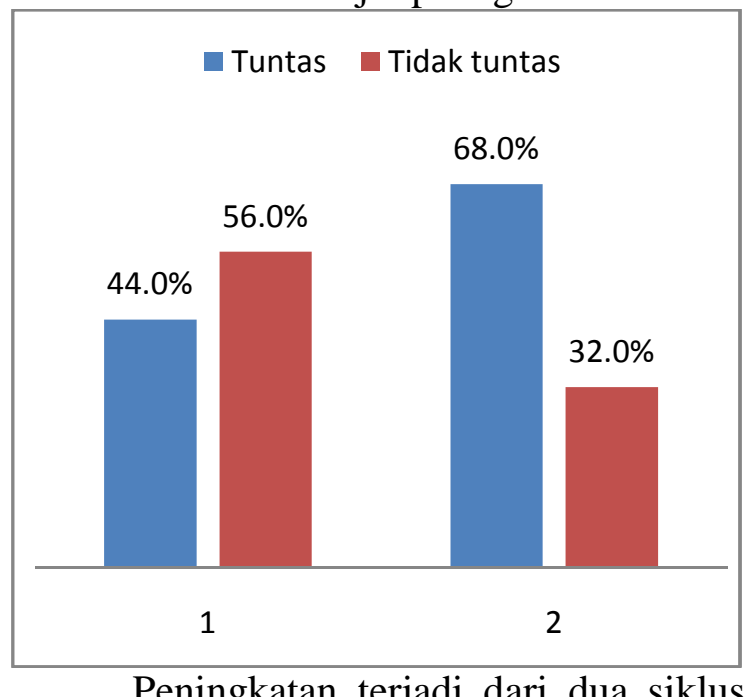

Peningkatan terjadi dari dua siklus

p.ISSN: $2407-800 X \quad$ e.ISSN: $2541-4356$ 
yang dilakukan yakni pada semula siswa yang mendapatkan ketuntasan hanya mencapai $44 \%$, kemudian meningkat pada siklus kedua yakni sebanyak $68 \%$. Hasil ini memberikan gambaran bahwa atas dasar penekanan pada penerapan siklus 2 dibandingkan dengan siklus 1 yakni dalam rangka memberikan penugasan dengan diperiksa dan dibagikan secara langsung kepada siswa memberikan nilai semangat bagi siswa dalam mendapatkan nilai.

Dari hasil observasi dan data yang diperoleh, peneliti mengambil kesimpulan bahwa tindakan yang dilaksanakan pada siklus kedua dinyatakan lebih baik bila dibandingkan dengan siklus pertama dan penulis nyatakan cukup sampai di siklus 2 dikarenakan keterbatasan waktu dan sudah ada peningkatan yang signifikan dari pada siklus 1 .

\section{PEMBAHASAN}

Berdasarkan analisis data, dari penelitian ini dapat ditarik kesimpulan bahwa, penerapan metode belajar penugasan dalam rangka meningkatkan hasil pekerjaan rumah siswa di kelas $\mathrm{V}$ pada mata pelajaran matematika mengenai bilangan bulat ternyata hasil belajar siswa meningkat dengan signifikan.

Data yang diperoleh menunjukkan bahwa setelah dilakukan penerapan metode belajar penugasan, maka terbukti adanya pengaruh yang ke arah yang positif dalam meningkatkan hasil pekerjaan rumah siswa pada mata pelajaran matematika mengenai operasi hitung, penekanan ini dilakukan dengan memberikan hak kepada orang tua untuk melakukan pencontrengan tahapantahapan metode belajar penugasan dari yang dilakukan anaknya.

Hasil penelitian ini memperkuat hasil penelitian sebelumnya yakni penelitian Made yang mengatakan bahwa terjadi interaksi antara model pembelajaran dengan kemampuan numerik dimana ditemukan model pembelajaran kooperatif tipe STAD lebih sesuai untuk siswa dengan kemampuan numerik tinggi namun sebaliknya terjadi terhadap model pembelajaran konvensional.
(Ni Made Sunilawati, Nyoman Dantes, 2013) Pada dasarnya proses pembelajaran terdiri dari tiga komponen yaitu pengajar (guru), bahan ajar (materi), dan yang belajar (siswa). Peran guru sangatlah penting diantaranya dalam mengaktifkan dan mengefisienkan proses belajar di sekolah termasuk di dalamnya penggunaan metode mengajar yang sesuai. Metode pembelajaran merupakan faktor penting dalam menentukan hasil belajar matematika siswa. Menurut Roestiyah, dengan pemilihan dan penggunaan metode yang tepat untuk setiap unit materi pelajaran, maka proses interaksi pembelajaran yang terjadi dapat meningkat.(Rahmawati, 2011)

Belajar merupakan serangkaian perbuatan guru dan siswa atas dasar situasi dan kondisi yang menyenangkan. Kondisi yang menyenangkan dalam pembelajaran akan tercipta dengan sendirinya apabila guru dapat memainkan peran sedemikian sehingga strategi yang dilaksanakan dalam setiap tatap muka dengan siswa. Kondisi seperti ini merupakan cara guru dalam memanfaatkan waktu dan situasi sehingga tidak terasa bahwa sudah terjadi proses pembelajaran yang menyenangkan, tentu pelaksanaannya dengan metode mengajar bervariasi. (Maonde, 2012)

Metode mengajar bervariasi merupakan kombinasi dari berbagai metode mengajar seperti metode diskusi, metode pemecahan masalah, metode deduksi, metode induksi, metode tanya jawab, metode karya wisata, metode penemuan, metode analitis, metode sintesis dan lainlain. Selain mengetahui berbagai metode tersebut perlu dikombinasikan dengan berbagai keterampilan mengajar yaitu keterampilan membuka dan menutup pelajaran, keterampilan pengelolaan kelas, keterampilan diskusi kelompok kecil, keterampilan memberi penguatan dan keterampilan lainnya. Dari sekian metode mengajar jika dipadukan dengan berbagai keterampilan diharapkan siswa akan terdorong serta termotivasi untuk belajar matematika. (Maonde, 2012) 
Selain menguasai metode mengajar bervariasi dan berbagai keterampilan serta dapat memberikan umpan balik penilaian yang cocok, akhirnya pembelajaran matematika lambat laun akan menjadi tinggi. (Maonde, 2012)

Berdasarkan pembahasan tersebut maka dapat dijelaskan dengan penerapan metode pembelajaran dalam hal ini diterapkan metode penugasan, maka semakin membuat peserta didik mengalami peningkatan kemampuannya dalam belajar.

\section{SIMPULAN}

Berdasarkan hasil penelitian diketahui bahwa penerapan etode belajar penugasan dalam rangka meningkatkan hasil pekerjaan rumah siswa di kelas $\mathrm{V}$ pada mata pelajaran matematika mengenai bilangan bulat ternyata hasil belajar siswa meningkat dengan signifikan. Data yang diperoleh menunjukkan bahwa setelah dilakukan penerapan metode belajar penugasan, maka terbukti adanya pengaruh yang ke arah yang positif dalam meningkatkan hasil pekerjaan rumah siswa pada mata pelajaran matematika mengenai operasi hitung.

\section{DAFTAR RUJUKAN}

Alamati, r. M. (2013). Meningkatkan kemampuan siswa membaca puisi melalui metode pemberian tugas di kelas iii sd laboratorium ung kecamatan kota selatan kota gorontalo. Fkip ung, 43-44.
Krismanto, a. (2003). Beberapa teknik, model, dan strategi dalam pembelajaran matematika.

Maonde, h. F. (2012). Kesenjangan hasil belajar matematika ditinjau dari penerapan metode mengajar dan umpan balik penilaian, 3 .

Masjoko. (2015). Metode belajar mengajar.

Ni made sunilawati, nyoman dantes, i. M. C. E-mail: (2013). Pengaruh model pembelajaran kooperatif tipe stad terhadap hasil belajar matematika ditinjau dari kemampuan numerik siswa kelas iv sd. Jurnal pendidikan dasar, 3(1).

Rahmawati, d. (2011). Upaya meningkatkan pemahaman konsep matematika dengan menggunakan metode pemberian tugas dan resitasi pada kelas xi ipa sma negeri 1 seyegan sleman yogyakarta.

Saryanti, d. (2010). Meningkatkan motivasi belajar pendidikan agama islam melalui pemberian tugas pada siswa kelas iv sd $n$ mejing i ambarketawang gamping sleman yogyakarta. 